\title{
CHOICE OF SOLUTIONS IN PROBLEMS WITH A CONSTANT COMPONENT
}

\author{
V.-B. Vovk, P. Kvasnii, D. Brezgunova
}

Ivan Franko National University of Lviv Prospect Svobody 18, UA - 79008, Lviv, Ukraine

The economic and mathematical toolkit of choosing the options for implementing a complex of projects considered in this article is synthesized in a single-criterion formulation. However, in the project management system it is difficult and sometimes not even possible to make a singlecriterion evaluation of the project, but the described algorithm is also suitable for the case of a multi-criterion problem statement. It can also be applied and, if necessary, operated with a certain level of uncertainty to manage investment projects. In this article we used a classic project management method - a critical path method that allows, based on the duration of the work and the order of their execution, to calculate the timing and reserves of work and projects as a whole, taking into account the production resources and the feasibility of their expansion, considering also entity`s financial opportunities. For each project, information is collected about available funds and resources that can be pledged for future loans.

The considered problems of forecasting economic decisions are related to poorly structured problems due to the considerable complexity of cause and effect relationships of economic processes and production management. To study this problem, mathematical models of industrial management were considered, which take into account the most important factors influencing management decisions and which fit into the proposed decision support system.

The analysis of the process of making management decisions takes into account the need to create and use objectively justified methods that take into account factors in quantitative terms. In our case, the methods of economic and mathematical modeling were used and the toolkit for forecasting the plan of choice of options for the implementation of a complex of projects helps to improve the reliability of the evaluation of alternatives of the relevant indicators of the plan.

The economic-mathematical model of choosing the optimal strategy for project implementation, harmonization and coordination of the production process considering the timing of the execution of orders and the implementation of projects is based on simulation modeling of the distribution of production resources to execute orders and works of projects in order to minimize the total costs, characterizes the volume and efficiency of execution of works production capacity, manpower, transport capacity, market conditions, as well as terms of production, economic obligations. The models and algorithms of choice of management decisions before calculating the plan of use of production resources of a certain organization during the

(C) V.-B. Vovk, P. Kvasnii, D. Brezgunova, 2019 
implementation of a complex of projects allow to predict them with sufficient accuracy with statistical and expert input parameters. They can be used to predict the results of other economic processes characterized by fuzzy relationships between input and output parameters which may not be sufficiently formalized, but when it is possible to obtain expert information to construct mathematical dependencies of the model.

Keywords: mathematical models, imitation algorithm, complex of projects, production resources

Entrepreneurial activity in market conditions requires from business entities to make decisions taking into account the rapid change in the market situation, in particular with the unpredictability of competitors' actions and lack of time for appropriate response. Therefore, the main purpose of almost all business structures is to provide their production with the sufficient amount of required resources. Thus, it is reasonable to have a sound plan that will be based on a well-grounded forecast. Unfortunately, its creation cannot be done with a perfect precision, as market fluctuations and rapid changes in the real economy cause a mismatch between the reality and forecast. The forecasting tool itself, in our opinion, should take into account the timeliness of the forecast and the amount of resources needed to implement the production process. In order to make forecasting effective, it is necessary to have complete in content, volume and structure information and the ability to compare it in time by quantitative and qualitative indicators. And this can only be achieved by making full use of the economic-mathematical modeling and advanced computer technologies. Models are a tool that allows to perform the desired scientific experiment. Modernity gives the opportunity to take advantage of the existing domestic and foreign experience and achievements in mathematics and software as well as to make use of models of the database management system [1]. In such a system, any enterprise can be regarded as a complex system in which, under the influence of various factors, certain unplanned deviations occur, which alter the final result of the planned activity. The classification of such deviations should reflect the causes of their occurrence, regardless of origin (external or internal); the degree of their recurrence and the ability to develop a mathematical model of a specific production and non-production situation and process.

In our opinion, the optimal management solution can be provided by a simulation method and with the help of computer technologies and it should be performed in two modes of time - in simulation time of the simulated process and in the real time of implementation of the modeling algorithm by passing the simulated time for each model and the real time of the experiment.

We will consider the proposed approach for calculating a calendar plan of the use of production resources of a particular organization in the implementation of a set of projects. It should be noted that the nature of production requires adjustment and coordination of the entire production process.

The work may be performed by contractors of a specific specialization with the involvement of appropriate resources, including technical means. The work can be executed by performers of a certain specialization with the involvement of a fleet of machines and mechanisms. Quantitative composition of the production line of the $k$ specialty is indicated by the $m_{k}$ symbol. For each branch $(i, j) \in N$ of the technological graph, which corresponds to a uniquely defined work with the volume $V_{i j}$. For convenience, we will 
denote the work with numbers $r\left(r=1,2, \ldots R_{l}\right)$. Executors (teams of workers, individual specialists, machines, mechanisms, etc.) are characterized by productivity of work $(r, j)$ of the $k$ sort $-P_{k r}$, and cost of performance of a unit of the work $-c_{k r l}$, $(k=1,2, \ldots, K ; \quad r=1,2, \ldots R)$. Quantities can be interpreted as the cost per unit of work or the cost of replacement of one machine, for example, one shift or one unit of time spent doing this work. There are also specified quantities that include the cost of delivering a contractor to a work object, additional costs for training a contractor, or additional fundraising, or other costs - $M_{k}$; the start and end dates of the $l$ - project are respectively $T_{i}^{\mathrm{h}}$ and $T_{i}^{\bar{h}}$.

It is necessary to define a calendar plan for the implementation of a set of works by performers, which will not violate the regulatory deadlines $\left.T_{l}^{n}, T_{l}^{\kappa}, \quad l=1,2, \ldots, L\right)$, and the cost of implementation of all projects will be minimal. Such tasks have the character of multi-network scheduling of rational resource allocation.

To find a solution to this problem, we propose an algorithm based on simulation modeling of the production process that takes into account a fixed component, which includes the financial costs of the implementation of projects and additional involvement's costs. The essence of the algorithm in general is as follows. For each stage of the search process, a set of jobs $R_{t}$ and available, work-free performers are determined. When solving, for example, a fixed-charge transportation problem [1)] we determine the optimal linking of performers to the work. The criterion for this linking is the amount of the total cost of executing all the necessary work. The total cost is determined as follows:

$$
\Pi_{k r l}=\frac{c_{k r l}+V_{r l}+t_{k} d_{l}+M_{k}}{V_{r l}}, r=1,2, \ldots R ; l=1,2, \ldots L
$$

If the number of works does not match the number of free performers, or vice versa, fictitious performers or works are additionally introduced. The distribution of performers over each stage, determined at the corresponding iteration, remains unchanged.

This length of time, that is, its duration, is determined by the formula

$$
\min _{(r, l)}\left\{\frac{V_{r l}}{P_{k r l}}\right\}=\tau_{\eta}
$$

The amount of work for which the performers are assigned is reduced by the amount corresponding to the amount of work performed by the respective executor over time $\tau_{\eta}$. During the next step, we solve the new task of optimal assigning contractors to jobs that takes into account a new set of jobs. It is possible to predict the redistribution of contractors who are assigned to work and have not yet completed their part.

Such a process of gradual distribution of contractors by works lasts until all the works of the complex, shown by the graphs in Fig. 1, are reviewed. Based on the calculated intervals of work by the assigned executors, determine the start and end times of work, time reserves for these works, the coefficients of tension. Then determine the total time of work that is on the critical path $T_{\kappa p}$ of the network schedule. We check that if the condition is fulfilled $T_{\kappa p}^{l}<T_{\kappa}^{l}$, that is, whether the project mandatory deadlines are met for a given 
complex of objects. Fulfillment of this condition makes it possible to conclude that the found calendar plan of implementation of projects with the available production resources is optimal in terms of the total costs. If the mandatory deadline is not fulfilled, it is necessary to check whether the executors of the highest quality are assigned for tasks which compose the critical path. If so, then it is impossible to execute the project with the available production resources within the specified timeframe, in other words the task is not solvable. When there is an opportunity to assign more productive performers to the critical path, the critical path $T_{\kappa p}$ will be reduced, but due to the increased cost of project implementation.

In order to ensure the redistribution of a more productive executor to the work of a critical path, but of course, with higher costs, it is necessary to artificially reduce costs $\Pi_{r l}$.
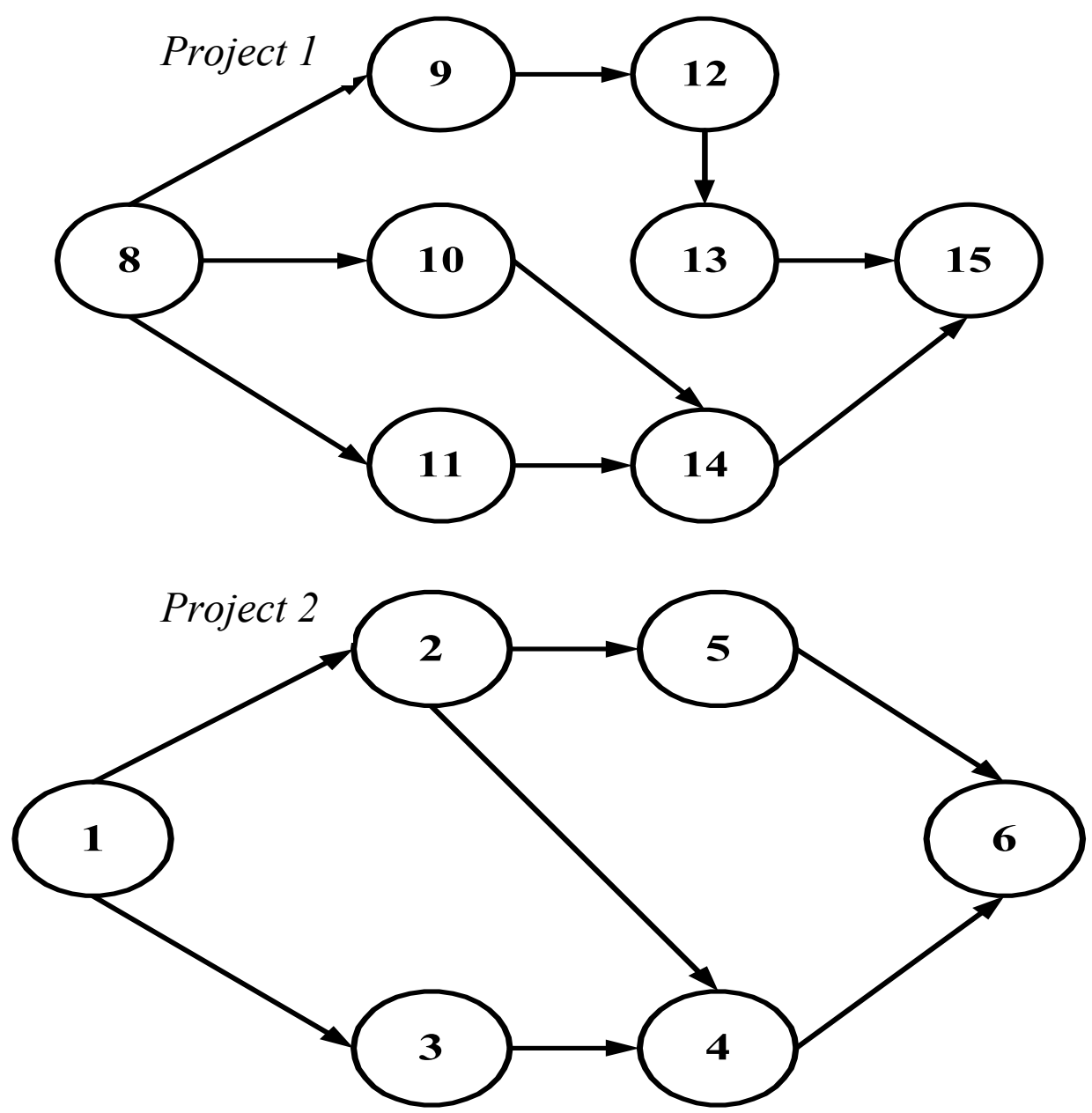

Figure 1. Networks of two projects 
The application of the proposed algorithm makes it possible to calculate a calendar plan of the use of all important production resources for efficient implementation of a complex of projects. An example of a such situation is as follows. Let's assume that it is necessary to ensure accomplishment of 2 projects that are remoted $5 \mathrm{~km}$ from one another. The cost of reassignment one executor of the first type for $1 \mathrm{~km}$ is $5 \mathrm{UAH}$, the second, the fourth and the fifth - $1 \mathrm{UAH}$, and the third - $33 \mathrm{UAH}$. The cost of preparatory work is considered only for the first and third type of executors. The obligatory deadline for the implementation of the works is 30 shifts. The amount of work, the variable productivity of executors, the cost of performing a unit of work, as well as the execution of preparatory work are shown in Table 1.

The technological sequence of the work is presented by the network in Fig. 2. The calculations are carried out at four stages. The linking remained unchanged at each step, lasting 9, 5, 5 and 7 shifts, respectively. Hence the total number of work shifts required for project implementation is equal to 26 . As a result, the mandatory deadline has been met and there is no need for a new calculations cycle to shorten project implementation time. Using step-by-step calculations, a calendar plan of work is drawn up, which is given in Table 1.

Table 1

Initial parameters of the project construction task

\begin{tabular}{|c|c|c|c|c|c|c|c|c|c|c|c|c|c|c|c|c|c|c|}
\hline \multirow{2}{*}{ 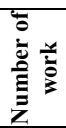 } & \multirow{2}{*}{$(i, j$} & \multicolumn{7}{|c|}{ First project } & \multicolumn{10}{|c|}{ Second project } \\
\hline & & 1,2 & 1,3 & 2,4 & 2,5 & 3,4 & 4,7 & 3,7 & 8,9 & 8,10 & 8,11 & 9,12 & 10,14 & 11,14 & 12,13 & 12,14 & 13,15 & 14,15 \\
\hline 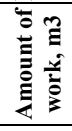 & $V_{i j}$ & 350 & 500 & 100 & 330 & 280 & 280 & 500 & 200 & 230 & 300 & 330 & 400 & 460 & 370 & 320 & 250 & 700 \\
\hline \multirow{5}{*}{ 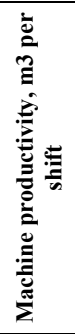 } & $P_{1 i j}$ & 50 & 60 & - & 40 & - & - & - & 40 & 50 & 60 & 50 & - & - & 60 & - & - & 100 \\
\hline & $P_{2 i j}$ & - & - & - & - & 30 & - & - & - & - & 10 & - & - & - & - & 20 & 20 & 80 \\
\hline & $P_{3 i j}$ & - & 100 & - & 450 & - & 75 & - & 23 & 15 & - & 70 & - & - & - & 65 & 30 & 70 \\
\hline & $P_{4 i j}$ & 40 & - & 30 & - & 40 & - & 80 & - & - & - & - & 80 & 100 & 75 & - & - & - \\
\hline & $P_{5 i j}$ & - & - & 20 & 70 & - & - & 60 & - & - & 25 & - & 60 & 800 & - & - & - & - \\
\hline \multirow{5}{*}{ 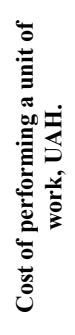 } & $C_{1 i j}$ & 1 & 1 & - & 3 & - & - & - & 1 & 1 & 1 & 2 & - & - & 1 & - & - & 1 \\
\hline & $C_{2 i j}$ & - & - & - & - & 1 & - & - & - & - & 3 & - & - & - & - & 2 & 1 & 2 \\
\hline & $C_{3 i j}$ & - & 2 & - & 2 & - & 1 & 1 & 2 & 3 & - & 1 & - & - & - & 2 & 1 & 2 \\
\hline & $C_{4 i j}$ & 2 & - & 2 & - & 2 & - & 1 & - & - & - & - & 1 & 1 & 3 & - & - & - \\
\hline & $C_{5 i j}$ & - & - & 2 & 1 & - & - & 2 & - & - & 2 & - & 2 & 2 & - & - & 2 & - \\
\hline \multirow{2}{*}{ 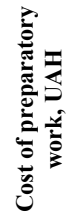 } & $M_{1}$ & 50 & 40 & - & 30 & - & - & - & 30 & 30 & 30 & 30 & - & - & 50 & - & - & 30 \\
\hline & $M_{2}$ & - & 20 & - & 20 & - & 10 & - & 10 & 10 & - & 20 & - & - & - & 20 & 20 & 20 \\
\hline
\end{tabular}


Direct mathematical programming methods can be used to solve these problems [1-3].

The considered economic-mathematical toolkit for choosing the options for the project implementation is synthesized in single-criterion formulation. However, it is difficult and sometimes even impossible to make a single-criterion assessment of a project in the project management system. For this case, use the multi-criteria formulation of the problem of choosing a project option.

The considered algorithm can be successfully used for calculating the optimal composition of contractors for executing a set of projects.

The use of the given algorithm for this case consists in formation of a sufficiently large number of performers, each type of which makes it possible to perform the required amount of work. With this algorithm determine the calendar plan for the implementation of a complex of projects, the composition of executors. Performers that are not enough engaged in construction are excluded from this composition.

After each such reduction of performers, it is necessary to re-calculate the optimal schedule. This will continue until performers with an allowable intensity of engagement will be selected. The second way of forming the optimal composition of executors is that there is a range of sets of executors and for each such set, the algorithm of calculating the optimal calendar plan for the implementation of projects of this object is applied. The set of executors for which the construction is the cheapest will be a priority.

Table 3

Schedule of linking machines to the work of construction sites

\begin{tabular}{|c|l|l|l|l|}
\hline \multirow{2}{*}{ Executors } & \multicolumn{3}{|c|}{ Shifts } & $20-26$ \\
\cline { 2 - 5 } & $1-9$ & $10-14$ & $15-19$ & 14,15 \\
\hline 1 & 1,3 & 8,10 & 12,13 & 13,15 \\
\hline 2 & 8,11 & 3,4 & 3,4 & 4,7 \\
\hline 3 & 8,9 & 9,12 & 12,14 & 5,7 \\
\hline 4 & 1,2 & 11,14 & 10,14 & - \\
\hline 5 & 8,11 & 2,5 & 2,4 & \\
\hline
\end{tabular}

The considered algorithm made it possible not only to calculate the schedule of execution of projects before their actual accomplishment, but also to promptly adjust the calendar plan in the process of its implementation in case of changing production conditions or opportunities. The latter may include, for example, changing the composition of executors, disrupting supplies of materials or equipment, etc.

Among the classical methods of managing uncertainty in models of investment projects management, one can also distinguish in this work methods based on fuzzy set theory, probability theory, and principles of simulation modeling. It should be noted that virtually all deterministic project management models have their probabilistic counterparts.

The classical project management method is the critical path method, which, based on the duration of the work and the order of their execution, calculates the terms and reserves of the work and the project in general, has a probabilistic analogue - the PERT method.

It should also be noted that for each of the projects, information is collected about the available funds and resources that can be pledged to banks for future loans, these data are capital constraints, as each investment provided must be secured.

The problems of forecasting economic decisions are related to poorly structured problems because of the considerable complexity of the cause and effect relationships of economic processes and production management.

Mathematical models of industrial management were used to study this problem, which take into account the most important factors influencing management decisions and which fit into the proposed method for calculating option that supports decision-making. 
The results of a comprehensive analysis of the process of executing work and making management decisions revealed the need to create and use objectively justified methods that would take into account factors in quantitative terms and such methods are methods of economic and mathematical modeling. Therefore, the use of any level of excellence in the tools of forecasting indicators of calculated solutions can not ensure the maximum level of their accuracy. These indicators, under the influence of random factors, can change significantly, which in turn may lead to the inadequacy of the calculated project implementation plan. The mathematical toolkit of forecasting the production plan helps to improve the reliability of the assessment of alternatives to the corresponding indicators of the financial plan.

Economic-mathematical model of choosing the optimal project implementation strategy, which characterizes the scope and efficiency of work execution. These characteristics are determined by the indicators of production capacity, manpower, transport capacity, market conditions, as well as the timing of production, economic obligations.

In order to harmonize and coordinate the production process with regard to the timing of the execution of orders and the implementation of projects, a method based on simulated modeling of the distribution of production resources is used for the execution of orders and works of projects in order to minimize the total costs. Due to accepted assumptions about the possibility of raising funds, the implementation of all projects and fulfillment of all commitments is possible.

The models and algorithms of choice of management decisions allow to predict them with sufficient accuracy at statistical and expert input parameters. They can be used to predict the results of other economic processes characterized by fuzzy relationships between input and output parameters and may not be sufficiently formalized, but it is possible to obtain expert information to build mathematical dependencies of the model.

1. Вовк В. М. Математичні методи дослідження операцій в економіко-виробничих системах : монографія / В. М. Вовк. - Львів : Видавничий центр ЛНУ ім. Івана Франка, 2007. - 584 с.

2. Ковальова К. О. Програмна реалізація задачі про розподіл транспортних засобів 3 фіксованими доплатами / Ковальова К. О., Місюра С. Ю. // Бізнес-інформ. №5 2018. c. 167-173 [Electronic resourse]. - Access mode : https://www.businessinform.net/export_pdf/business-inform-2018-5_0-pages-167_173.pdf

3. Kennington J. L. Fixed-charge transportation problem: a group theoretic approach : thesis / Georgia Institute of Technology, 1973. - $126 \mathrm{p}$.

\section{References}

1. Vovk V. M. (2007) Matematychni metody doslidzhennia operacii v ekonomikovyrobnychykh systemax [Mathematical methods of operations research in economic and production systems], Lviv : Vydavnychyi centr LNU im. Ivana Franka. 584 p. [in Ukrainian]

2. Kovaliova K. O., Misyura Ye. Yu. (2018) Programna realizaciya zadachi pro rozpodil transportnykh zasobiv z fiksovanymy doplatamy [Software implementation of the problem of vehicles distribution with fixed surcharges], Business-Inform, №5 p. 167 173. Available at https://www.business-inform.net/export_pdf/business-inform-20185 0-pages-167 173.pdf [in Ukrainian]

3. Kennington J. L. (1973) Fixed-charge transportation problem: a group theoretic approach : thesis / Georgia Institute of Technology, $126 \mathrm{p}$. 


\title{
ПРИЙНЯТТЯ РІШЕНЬ В ЗАДАЧАХ 3 ПОСТІЙНОЮ КОМПОНЕНТОЮ
}

\author{
В.-Б. Вовк, П. Квасній, Д. Брезгунова
}

Львівський національний університет імені Івана Франка 79008 м. Львів, проспект Свободи, 18

Розглянутий в даній статті економіко-математичний інструментарій вибору варіантів виконання комплексу проектів синтезований в однокритеріальній постановці. Однак у системі управління проектами важко, а іноді навіть неможливо зробити однокритеріальну оцінку проекту, але описаний алгоритм годиться і для випадку багатокритеріальної постановки задачі. Також його можна застосовувати і при необхідності оперувати з певного рівня невизначеністю для управління інвестиційними проектами.

В даній статті застосований класичний метод керування проектами — метод критичного шляху, який дозволяє на основі тривалості робіт і порядку їхнього виконання обчислити терміни і резерви виконання робіт і проектів в цілому 3 врахуванням обсягів виробничих ресурсів та допустимістю їх розширення, враховуючи фінансові можливості, Для кожного 3 проектів збирається інформація про наявні засоби і ресурси котрі можуть бути закладені під гарантії майбутніх кредитів

Розглянуті проблеми прогнозування економічних рішень відносяться до слабо структурованих проблем через значну складність причинно-наслідкових зв'язків економічних процесів та виробничого менеджменту. Для вивчення цієї проблеми було розглянуто математичні моделі виробничого менеджменту, які враховують найвагоміші чинники впливу на управлінські рішення і які вписуються у запропоновану систему підтримання прийняття рішень.

За результатами аналізу процесу вироблення і прийняття управлінських рішень врахована необхідність створення і використання об'єктивно обгрунтованих методів, які врахували чинники у кількісному вираженні. В нашому випадку використано методи економіко-математичного моделювання та інструментарій прогнозування плану вибору варіантів виконання комплексу проектів сприяє покращенню достовірності оцінки альтернатив відповідних показників плану.

Економіко-математична модель вибору оптимальної стратегії реалізації проектів, узгодження і координації виробничого процесу з врахуванням термінів виконання замовлень та реалізації проектів базується на імітаційному моделюванні розподілу виробничих ресурсів для виконання замовлень і робіт проектів з метою мінімізації сумарних витрат, характеризує обсяги та ефективність виконання робіт через показники виробничих потужностей, трудових ресурсів, транспортних можливостей, ринкових кон'юнктури, а також терміни виконання виробничих, господарських зобов'язань.

Розглянуті моделі і алгоритми вибору управлінських рішень до розрахунку календарного плану використання виробничих ресурсів певної організації під час виконання комплексу проектів дозволяють 3 достатньою достовірністю їх прогнозувати при статистичних i експертних вхідних параметрах. Вони можуть бути використані при залученні коштів для реалізація всіх проектів і виконання всіх взятих зобов'язань. для прогнозування результатів інших економічних процесів, які характеризуються нечіткими зв'язками між вхідними та вихідними параметрами і не можуть бути достатньо формалізованими, але є можливість отримувати експертну інформацію для побудови математичних залежностей моделі.

Ключові слова: математичні моделі, імітаційний алгоритм, комплекс проектів, виробничі ресурси. 